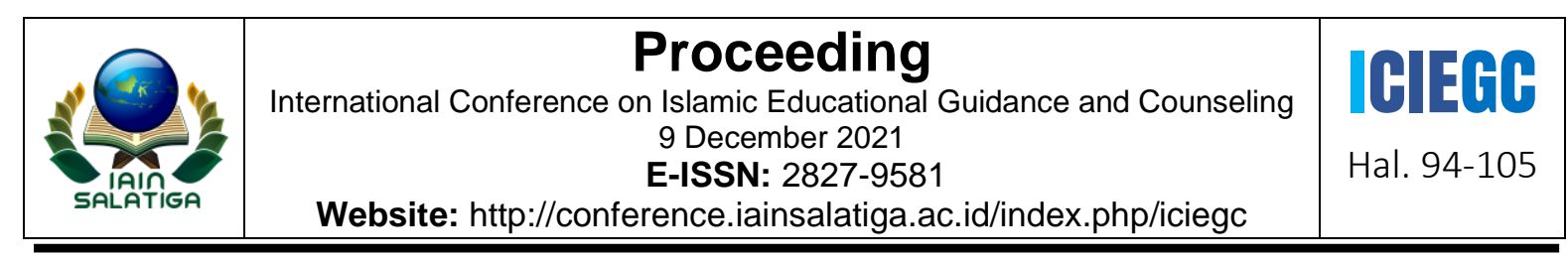

\title{
KONSELING ONLINE BERBASIS TEKS: KETERAMPILAN, GAYA, DAN SIKAP BERKOMUNIKASI
}

\author{
Abi Fa'izzarahman Prabawa ${ }^{1}$ \\ ${ }^{1}$ IAIN Salatiga
}

\begin{tabular}{l}
\hline \hline Informasi Artikel \\
\hline Penulis Korespondensi: \\
Abi Fa'izzarahman Prabawa \\
Email: \\
abiprabawa@iainsalatiga.ac.id
\end{tabular}

\begin{abstract}
The implementation of text-based online counseling through social media becomes one of the favorite choices for counselor and counselee. This article aims to describe the skills, styles, and attitudes of counselors in communicating using text. This research uses a method of literature study. Text-based online counseling services are communication between counselors and counselee with text reply in a chat room. The implementation of text-based online counseling has five phases, namely: establishing good rapport, assessment, goal setting, engagement, and termination and followup. The success and effectiveness of text-based online counseling depends on mastering competence and communication skills through text. Basic technological competencies, text-based counseling competencies, and text-based online counseling skills, among others: writing skills, writing style, and attitudes in writing are important to master.
\end{abstract}

Kata kunci: Konseling online; berbasis teks; komunikasi

\section{PENDAHULUAN}

Saat ini masyarakat dunia memasuki era transformasi digital yang dikenal dengan Society 5.0. Istilah society 5.0 pertama kali dicetuskan oleh pemerintah jepang pada tahun 
2016 yang secara masif mempengaruhi tatanan nilai kehidupan di berbagai negara (Fukuyama, 2018). Konsep society 5.0 memiliki perbedaan dengan society 4.0 yang fokus dalam mengoptimalkan perkembangan industri. Society 5.0 menempatkan manusia sebagai pusat inovasi (human-centered). Dengan kata lain, kemajuan teknologi dapat meningkatkan kualitas kehidupan, tanggungjawab sosial, dan perkembangan berkelanjutan (Usmaedi, 2021).

Kemajuan teknologi berdapat juga pada layanan konseling. Komunikasi konseling pada umumnya dilakukan secara langsung, namun melalui kecanggihan teknologi konseling dapat dilaksanakan secara online. Konseling melalui media online dikenal dengan konseling online. Konseling online memiliki banyak istilah lain, yaitu: e-konseling, e-terapi, epsikoterapi, konseling internet, konseling web, cybercounseling, psikoterapi internet, dan konseling online (Germain, et al., 2009; Patrick, 2006). Secara umum, konseling online dimaknai sebagai komunikasi konseling yang dilakukan dengan memanfaatkan media online.

Pelaksanaan konseling online melalui media online dapat dilakukan dengan modalitas yang berbeda. Modalitas dalam konseling online ada dua jenis, yakni synchronous dan asynchronous (Kraus et al., 2011; Murphy \& Mitchell, 1998). Asynchronous merupakan komunikasi yang bersifat satu arah, seperti komunikasi melalui e-mail, radio, televisi. Synchronous merupakan komunikasi yang bersifat dua arah sehingga memungkinkan konselor dan konseli dapat berkomunikasi secara langsung melalui alat komunikasi (realtime) seperti: telepon, videoconference, dan chat-text (Kraus et al., 2011; Mallen et al., 2005). Modalitas synchronous masih dibagi menjadi dua macam tipe. Tipe pertama adalah menggunakan media videoconference. Videoconference memiliki kelebihan yakni dapat berkomunikasi menggunakan video sehingga memungkinkan komunikasi tatap maya. Tipe selanjutnya adalah chat-text, media komunikasi dengan berbasis teks, seperti: whatssapp atau telegram. Jika dibandingkan videoconference, modalitas chat-text lebih hemat kuota dan tidak memerlukan jaringan internet yang kuat (Mallen et al., 2005; Kraus et al., 2011). Hal tersebut menjadi kelebihan dari chat-text dibanding videoconference.

Hasil riset Trisnasi (2017) dan Sugiarti (2020), media sosial whatssapp gandrung digunakan oleh berbagai kalangan, terutama siswa. Oleh karena itu, saat ini whatsapp menjadi media sosial pilihan bagi para konselor dan siswa. Beberapa riset terkait dengan penggunaan whatsapp dalam konseling, diantaranya: 1) layanan informasi melalui WA; 2) layanan bimbingan kelompok melalui WA, 3) konseling online melalui WA (Sugiarti, 2020; Budianto, dkk., 2019; Prihwanto \& Firdaus, 2021). Berdasar pada beberapa riset tersebut 
dapat dimaknai bahwa saat ini media sosial whatsapp berpotensi sering digunakan sebagai media layanan konseling.

Pelaksanaan konseling online melalui media sosial yang berbasis teks saat ini menjadi salah satu pilihan dari para guru dan siswa. Beberapa keunngulannya adalah hemat kuota dan tidak memerlukan jaringan internet yang kuat (Mallen et al., 2005; Kraus et al., 2011). Oleh karenanya, seorang konselor perlu sebuah keterampilan dalam memberikan layanan konseling melalui whatsapp. Artikel ini bertujuan untuk mengkaji keterampilan, gaya, dan sikap konselor dalam berkomunikasi dengan menggunakan teks.

\section{METODE}

Metode penelitian yang digunakan adalah metode penelitian studi kepustakaan (library research). Studi kepustakaan dimaknai sebagai rangkaian kegiatan riset yang dilakukan dengan pengumpulan sumber literatur, membaca, dan mengolah serta mengkaji literatur berdasarkan topik penelitian (Mirzaqon \& Purwoko, 2018). Penelitian ini menggunakan sumber primer dan sekunder. Sumber primer berasal dari artikel hasil penelitian dan sumber sekunder dari buku, bahan ajar, dokumen, dst. Prosedur yang dilakukan dalam riset ini meliputi: 1) pemilihan topik; 2) eksplorasi informasi; 3) menentukan fokus penelitian; 4) pengumpulan sumber data; 5) persiapan penyajian data; dan 6) penyusunan laporan (Mirzaqon \& Purwoko, 2018).

\section{HASIL DAN BAHASAN}

\section{Hakikat konseling online berbasis teks}

Layanan konseling online berbasis teks merupakan komunikasi antara konselor dan konseli dengan berbalas teks di sebuah ruang obrolan (Kraus et al., 2011). Komunikasi melalui teks dapat dilakukan secara sinkron ataupun asinkron. Melalui kecanggihan teknologi, saat ini banyak penyedia layanan pengiriman pesan yang bersifat sinkron (realtime), seperti: whatsapp, telegram, facebook, dst. Komunikasi berbasis teks melalui whatsapp dapat diilustrasikan sebagai berikut. Konselor dan konseli harus melakukan registrasi di whatsapp. Konselor dan konseli dapat membuka percakapan dan mulai untuk membuat kontrak ataupun kesepakatan konseling. Selanjutnya, konselor dan konseli dapat melakukan konseling sesuai dengan hasil kesepakatan. Konselor dan konseli tidak hanya dapat mengirim teks, namun juga dapat mengirim pesan suara, gambar, emoticon, video, atau musik. Fitur-fitur nonteks tersebut akan membantu kedua belah pihak dalam memahami warna emosi yang sedang dirasakan saat itu (Kraus et al., 2011). 


\section{Kompetensi dalam konseling online berbasis teks}

Asosiasi Konseling \& Psikoterapi Inggris memberikan sebuah panduan kompetensi yang harus dimiliki oleh seorang konselor dalam pelaksanaan konseling online. Terdapat dua kompetensi yang perlu dimiliki oleh konselor, yakni: kompetensi dasar teknologi dan kompetensi konseling berbasis teks (CCPA, 2019).

Kompetensi dasar teknologi merupakan kopetensi yang perlu dimiliki oleh konselor untuk mengoperasikan media konseling yang dipakai. Kompetensi tersebut diantaranya (CCPA, 2019):

1. Enkripsi. Konselor hendaknya mengetahui cara kerja dan cara menggunakan enkripsi. Enkripsi berfungsi untuk menjaga pesan yang dikirim ataupun diterima oleh pengguna media. Pesan yang dikirim dengan enkripsi akan terjaga kerahasiaannya dan meminimalisir terjadinya pencurian data, sebab hanya pengirim dan penerima pesan saja yang dapat membaca pesan tersebut.

2. Sistem pencadangan. Konselor mengetahui cara untuk mencadangkan dan mengekspor data cadangan. Fungsi dari sistem pencadangan adalah mengarsipkan data-data yang masih diperlukan ke dalam memori. Misalkan data konseling dimasukkan kedalam sistem pencadangan agar jika sewaktu-waktu dibutuhkan dapat diekspor kembali.

3. Password keamanan. Konselor perlu mengetahui cara untuk membuat password yang aman agar data tersimpan dengan baik.

4. Firewall. Konselor perlu mengetahui fungsi dari firewall. Firewall merupakan sistem pertahanan untuk mencegah akses data yang tidak diinginkan

5. Anti virus. Konselor perlu mengetahui peran dan cara menggunakan anti virus. Pelaksanaan konseling online tidak dapat berjalan tanpa adanya media dan internet. Akses internet sangat perpotensi terserang virus yang dapat mengancam data-data penting. Oleh karenanya, penting konselor mengetahui cara penggunaan antivirus untuk menjaga data-data konseling.

6. Perangkat keras (Hardware). Konselor penting mengetahui tentang spesifikasi perangkat yang digunakan untuk konseling online. Laptop, hp, komputer, headset, mikropon, kamera merupakan perangkat keras yang digunakan untuk mendukung pelaksanaan konseling online. Semakin bagus spesifikasinya maka semakin berdampak baik terhadap pelaksanaan konseling online. 
7. Perangkat lunak. Konselor perlu memiliki pengetahuan tentang perangkat lunak. Perangkat lunak merupakan aplikasi yang digunakan untuk melakukan layanan konseling online. Konselor hendaknya dapat melakukan instalasi, registrasi, dan menggunakan aplikasi tersebut. Perangkat lunak yang dimaksud seperti: whatsapp, telegram, instagram, zoom, dst.

8. Internet. Konselor hendaknya mengetahui tentang kinerja internet. Semakin bagus kekuatan jaringan internet maka semakin bagus pula grafis dan suara yang dihasilkan.

Kompetensi yang perlu dimiliki oleh konselor dalam pelaksanaan konseling online berbasis teks, diantaranya (CCPA, 2019):

1. Memahami cara menulis yang membantu (terapeutik)

2. Mengidentifikasi hal-hal yang mendukung pelaksanaan konseling online

3. Mengidentifikasi dan mengelola risiko saat melakukan konseling online;

4. Menetapkan batasan-batasan konseling online;

5. Mengetahui bagaimana mengelola dampak disinhibisi

\section{Keterampilan komunikasi dalam konseling online berbasis teks}

Komunikasi dalam konseling online berbasis teks sangat bergantung pada kemampuan dalam menulis kalimat yang terapeutik. Hal ini menjadi tantangan bagi konselor untuk dapat secara responsif dan luwes untuk berkomnikasi dengan menggunakan teks. Konselor yang sangat mahir untuk berbicara dalam konseling tatapmuka belum tentu mahir dalam konseling berbasis teks. Keberhasilan dan kefektifan pelaksanaan konseling online berbasis teks sangat bergantung pada kemampuan konselor untuk menulis. Konselor yang memiliki minat untuk menulis, sangat berpotensi untuk lebih dapat mengekspresikan melalui tulisannya. Konselor yang memiliki minat dalam menulis akan mudah dalam menyusun kalimat, memilih diksi yang tepat, serta lebih presisi dalam memanifestasikan pikiran dan perasaan.

Terdapat tiga keterampilan yang perlu dikuasai dalam konseling online berbasis teks, diantaranya (Kraus et al., 2011):

1. Keterampilan menulis

Kualitas hubungan yang terbentuk dalam konseling online berbasis teks bertumpu pada keterampilan menulis. Hubungan antara konselor dan konseli akan berkembang dan begitu dalam ketika konselor ataupun konseli dapat mengekspresikan diri melalui tulisan. Keterampilan dalam menulis yang buruk akan berpotensi terjadinya kesalah pahaman dan memicu sebuah konflik. Hal utama yang perlu dimiliki oleh konselor adalah ketajaman 
dalam mempresepsikan, kelapangan hati, dan cara berfikir yang rasional dalam memaknai sebuah tulisan. Tidak akurat dalam mempresepsikan sebuah tulisan, akan membuat konselor memiliki sebuah pemikiran dan perasaaan yang dimaknai sendiri tanpa melihat sudut pandang orang lain. Sebaiknya keduanya belah pihak memiliki keterampilan menulis yang baus sehingga tercipta suatu hubungan komunikasi yang adil dan hangat. Contoh kasus, konseli sangat terbuka dan berusaha mengekspresikan dirinya, namun konselor tidak tidak menanaggapi dengan responsif maka yang terjadi adalah konseli merasa tidak aman karena telah membuka diri. Sebaliknya, konselor dengan ekspresif mengajak untuk berdialog namun konseli adalah orang yang tertutup, sehingga membuat konseli merasa dihakimi. Oleh karena itu, penting bagi konselor untuk berkreasi, melakukan variasi dalam menulis, dan memilih diksi yang efektif dan terapeutik. Seperti halnya dalam berkomunikasi langsung, konselor perlu melakukan variasi keterampilan komunikasi seperti: reflection of feeling, restatement, leading, silence, dan sebagainya.

Tabel 1. Definisi Asli dan Kesalahan Definisi Emoji

\begin{tabular}{llll}
\hline Emoji & Nama & Definisi Asli & Kesalahan Definisi \\
\hline & $\begin{array}{l}\text { Wajah dengan air } \\
\text { mata kebahagiaan }\end{array}$ & $\begin{array}{l}\text { Sesuatu yang lucu dan } \\
\text { menyenangkan }\end{array}$ & Menangis keras \\
\hline & $\begin{array}{l}\text { Tolong, Terimakasih, atau } \\
\text { Berdoa }\end{array}$ & Tos \\
\hline $\begin{array}{l}\text { Wajah Mengantuk } \\
\text { dari hidung }\end{array}$ & $\begin{array}{l}\text { Lelah atau Wajah tidur dalam } \\
\text { animasi }\end{array}$ & Wajah Menangis \\
\hline & $\begin{array}{l}\text { Iritasi, Marah, atau Penghinaan } \\
\text { Wajah diam }\end{array}$ & Wajah dengan kekawatiran & Wajah bangga \\
\hline & $\begin{array}{l}\text { Wajah sedih tapi } \\
\text { lega }\end{array}$ & Kekawatiran atau kecemasan tercengan \\
\hline
\end{tabular}


Konselor juga dapat mengekpresikan perasaan dengan menggunakan variasi emoji. Penggunaan emoji dalam konseling berbasis teks memiliki beberapa manfaat, diantaranya: a) meningkatkan kehangatan dan keakraban, b) merepresentasikan keramahan, c) mengurangi efek negatif dan memperkuat efek positif, d) emoji dapat memperkuat makna tulisan yang dimaksud, dan e) variasi dalam menulis. Hal yang menjadi catatan adalah isarakan untuk tidak terlalu sering menggunakan emoji karena dapat berdapak negatif. Konseli akan merasa bahwa konselor tidak tulus dan berpura-pura (Byron \& Baldrige, 2007; Jansen et al., 2014; Tang \& Hew, 2019). Konselor dapat menggunakan beberapa emoji yang disedikan dalam media konselig. Hal yang perlu menjadi perhatian adalah jangan sampai salah mengirimkan emoji karena dapat memicu terjadinya konflik atau salah paham. Maka seorang konselor harus paham makna dari emoji yang digunakan. Bai et al., (2019) mengemukakan ada beberapa emoji yang disalahartikan. Beberapa emoji yang disalahartikan atau menyimpang dari definisi aslinya terlihat dalam tabel 1.

Kondisi hubungan dalam konseling online juga memiliki pengaruh terhadap kualitas penulisan. Hubungan konseling yang dalam dan hangat biasanya akan memicu konseli untuk menulis dengan terbuka, lengkap, dan luwes. Konseli yang sudah percaya terhadap konselor, cenderung lebih ekspresif dalam mengungkapkan diri dan mau mengambil resiko dalam menyampaikan fikiran dan perasaan yang terjadi, serta dalam meracik komposisi tulisan. Komposisi tulisan seseorang bersifat dinamis sesuai dengan perkembangan hubungan. Komposisi tulisan akan lebih baik jika konseli merasa aman, sebaliknya akan lebih menurun ketika merasa terancam, terluka, ataupun marah.

\section{Gaya menulis}

Gaya menulis ada hubungannya dengan kepribadian seseorang. Cara seseorang mengekspresikan diri (konkret, abstrak, emosional); pemilihan kosakata dan struktur kalimat; alur berfikir mencerminkan kepribadian sesorang dan berpengaruh terhadap cara orang mereaksi. Gaya menulis konselor merupakan cerminan diri dari kepribadian konselor dan konseli akan cenderung mereaksi sesuai dengan gaya tulisan konselor. Orang yang bersifat kompulsif cederung menulis dengan terstruktut, logis, formal, sedikit kesalahan tulisan. Orang yang bersifat histrionik memiliki kecendrungan untuk menulis secara dramatis dan lebih ekspresif dalam memainkan jenis huruf, spasi, kapital, karakter yang unik, dan bahasa yang berbunga-bunga. Orang yang bersifat narsis mungkin akan menulis dengan bertele-tele dan panjang. Orang yang bersifat skizoid atau menghindari interaksi sosial akan cenderung menulis dengan padat dan jelas. Orang yang impulsif cenderung 
menulis dengan kurang terstruktur dan menggunakan frasa emosional yang disorot dengan huruf besar. Gaya menulis dan kepribadian tersebut bisa jadi sama ataupun berbeda dan memungkin komplemen dari satu gaya dengan gaya yang lainnya.

3. Bersikap dalam menulis

Sikap seseorang dalam menulis memiliki peran penting dalam konseling berbasis teks. Tidak menutup kemungkinan tulisan-tulisan akan membawa kenangan dan situasi masa lalu. Hal tersebut penting untuk konselor ketahui agar konselor mampu untuk melakukan leading dan menguasi situasi/kondisi. The ISMHO Clinical Case Study Group (2001) menyarakan kepada konselor pada awal konseling untuk mengidentifikasi keterampilan, sikap, dan pengalaman konseli dalam membaca dan menulis. Konselor perlu memberikan sebuah pemahaman bahwa kemampuan konseli dalam membaca, menulis/mengetik sangat diperlukan dalam konseling online berbasis teks. Selain itu, konselor juga perlu mengingat bahwa kemampuan konselor dalam membaca dan mengetik akan diperlukan dalam membangun komunikasi yang terapeutik selama proses konseling. Pada konseling berbasis teks, konselor perlu mendorong konseli untuk mengekpresikan diri dalam sebuah kalimat/teks untuk memperkuat proses terapeutik.

\section{Tantangan konseling online berbasis teks}

Proses konseling melalui konseling online berbasis teks secara umum sama seperti proses konseling pada umumnya. Konseling online berbasis teks melibatkan konselor dan konseli yang bekerjasama secara kooperatif untuk mengidentifikasi masalah dan menemukan solusi terbaik (Hardy, 2008; Kraus et al., 2011). Konteks percakapannya yang dibentuk adalah membahas kondisi konseli saat ini dan alternatif pemecahan masalah dari konselor. Alternatif pemecahan masalah yang diberikan konselor diharapkan dapat diimplementasikan oleh konseli dalam kehidupannya. Pada akhirnya konseli memiliki perspektif baru dalam hidupnya, menemukan keterampilan hidup baru, atau mencapai tujuan yang telah ditetapkan dalam sesi konseling.

Perlu dipahami bahwa perbedaan dari pelaksanaan konseling online dengan konseling pada umumnya terletak pada medianya saja. Konseling online menggunakan media online sebagai media percakapan konselor dengan konseli sedangkan konseling tatap muka bertemu secara langsung. Adapun secara teknis pelaksanaan keduanya sama, sama-sama menggunakan tahapan, strategi, dan intervensi yang sama (Anthony \& Nagel, 2010; Kraus et al., 2011). 
Pada saat proses konseling, konselor haruslah reponsif menyesuaikan nada percakapannya dengan konseli sehingga tetap tercipta suasana percakapan yang hangat, nyaman, dan terbuka (Kraus et al., 2011). Tantangan konselor dalam konseling online berbasis teks adalah keterampilan memahami setiap kata yang diketik, emoticon yang dipilih, besar kecil ukuran font, kapital, warana font, dan seterusnya. Kemampuan konselor dalam memahami dan menafsirkan tersebut berpengaruh dalam suasana komunikasi yang terbentuk. Kondisi tersebut nantinya akan bermuara pada tercetusnya solusi terbaik atas masalah yang dihadapi oleh konseli.

\section{Fase pelaksanaan konseling online berbasis teks}

Pelaksanaan konseling online berbasis teks secara garis besar seperti konseling tatap muka pada umumnya. Terdapat beberapa fase yang harus dilakukan oleh konselor dalam pelaksanaan konseling online berbasis teks. Hal yang menjadi tantangan dari konselor selain empati memahami konseli adalah menguasai keterampilan menulis sebagai proses terapeutik. Berikut ini adalah kisi-kisi fase pelaksanaan konseling online berbasis teks. Terdapat lima fase dalam pelaksanaan konseling online berbasis teks (Kraus, et al., 2011).

\section{Membina hubungan baik}

Membina hubungan baik terjadi ketika konselor dan konseli sama-sama merasakan kehadirannya, merasakan perhatian, dan kenyamanan. Pada konseling tatap muka pembinaan hubungan dapat dirasakan secara langsung melalui kehadiran fisik, berbeda dengan konseling online berbasis teks. Memberikan perhatian, pemahaman, dan dukungan adakah hal yang perlu diberikan pada saat pembinaan hubungan baik. Tantangannya sebagai konselor online adalah menciptakan kehadiran tersebut dengan kreasi dalam menulis pesan dan merespons dengan hangat. Misalkan: pada saat dalam kondisi diam/jeda, konselor dapat merepsons dengan mengirimkan teks, "baik, tidak perlu terburu... saya berikan waktu untuk berifikir". Contoh lainnya adalah memberikan dukungan dengan mengirimkan emoji tersenyum "-)". Strategi tersebut adalah hal yang dapat dilakukan untuk membangun hubungan baik dalam konseling online berbasis teks (Anthony, 2000).

2. Asesmen

Asesmen pada konseling online berbasis teks implementasinya sama seperti asesmen dalam konseling tatap muka. Konselor mengintepretasi perkataan konseli melalui variasi teknik komunikasi, seperti: "restating”, “paraphrasing”, "probing,", “giving feedback”, and “checking perceptions", dst. Selama sesi konselor dapat mengoptimalkan teknik komunikasi tersebut agar percakapan lebih mendalam, sebab konseli bisa saja hanya 
memaknai apa yang tertulis. Misalkan konseli menulis, "Saya merasa sedih karena pekerjaan saya. Tidak ada orang yang menghargai atas apa yang saya kerjakan”. Konselor dapat merespon dengan parafrase, "Saya merasa sedih mendengarnya. Sepertinya saudara merasa tidak dihargai di tempat kerja”. Teknik Probing dapat digunakan untuk mendalami informasi dan mengurangi salah tafsir. Misalkan dengan berkata, "Dapatkah engkau menceritakan lebih lanjut...". Memberikan pertanyaan kepada konseli tidak hanya membantu konselor memahami perkataan konseli namun akan membantu juga dalam membangun hubungan yang terapeutik. Teknik umpan balik dapat digunakan untuk membandingkan persepsi konseli dan membuka wawasan baru. Pada intinya konselor dapat memvariasikan keterampilan komunikasi kedalam sebuah tulisan.

\section{Menetapkan tujuan}

Menetapkan tujuan merupakan sebuah fase untuk memfasilitasi konseli merumuskan tujuan yang positif. Penetapan tujuan konseli dapat dilakukan secara direktif ataupun kolaboratif. Penetapan tujuan yang bersifat direktif, misalkan: "Saya ingin saudara bertemu dan melakukan konseling lagi minggu depan, bisakah saudara melakukan itu?”. Cara lain yang lebih kolaboratif dalam menetapkan tujuan adalah dengan bertanya, "Sepertinya Anda tidak merasa dihargai di tempat kerja. Ceritakan hal apa yang bisa mengalihkan dirimu dari hal tersebut?".

\section{Membangun hubungan terapeutik}

Pada fase ini konselor mengajak konseli untuk hadir dan mendalami situasi konseling yang terapeutik. Ketika hubungan yang terapeutik tersebut terjadi, maka konseli akan merasa diberikan dukungan dan merasa dibantu oleh konselor. Konseli bisanya memberikan respons yang positif, misalkan konseli mengucapkan, "Terimakasih" atau "Saya sadar..." atau bahkan memberikan emoji “()”. Konselor akan dapat merasakan konseli mengalami keterlibatan yang positif dalam sesi konseling. Hal tersebut dapat terbukti dari semamngat konseli dalam menjalankan rencana yang dibuat dan konseli melaporkan setiap perubahan positif yang dirasakan.

\section{Terminasi dan tindaklanjut}

Terminasi dan tindak lanjut merupakan fase terakhir dari konseling yang terapeutik. Seperti halnya dalam konseling tatap muka, pada fase ini konselor dapat menggunakan tekni "summary" untuk memberikan inti sari hasil konseling kepada konseli. Teknik "summary" dapat digunakan secara fleksibel oleh konselor selama proses berlangsung atau di akhir fase. Teknik "summary" pada saat sesi ebrlangsung biasanya digunakan untuk mensarikan topik 
yang telah dibahas dan ingin pindah ke topik lain. Teknik "summary" pada akhir fase digunakan untuk merangkum hasil konseling. Terakhir pada fase ini konselor memberikan kata penutup dengan merangkum hasil perubahan yang dicapai, perspektif baru, atau rekomendasi tindaklanjut. Tindak lanjut dapat dilakukan melalui tiga jalan, yaitu: a) meneruskan konseling dengan tatap muka, b) meneruskan konseling dengan konseling online kembali, atau c) melakukan referal atau alih tangan kasus.

\section{KESIMPULAN}

Layanan konseling online berbasis teks merupakan komunikasi antara konselor dan konseli dengan berbalas teks di sebuah ruang obrolan. Pelaksanaan konseling online berbasis teks memiliki fase yang harus dilalui, yaitu: membina hubungan baik, asesmen, menetapkan tujuan, membangun hubungan terapeutik, dan terminasi dan tindak lanjut. Diperlukan kompetensi konselor untuk melalui fase tersebut, yaitu: kompetensi dasar teknologi dan kompetensi konseling berbasis teks. Keberhasilan dan kefektifan pelaksanaan konseling online berbasis teks sangat bergantung pada penguasaan kompetensi dan keterampilan komunikasi melalui teks. Hal yang menjadi tantangan konselor dalam konseling online berbasis teks adalah keterampilan memahami setiap kata, emoji, besar kecil ukuran font, tulisan kapital, warna font, dan seterusnya. Maka, untuk menjawab tantangan tersebut diperlukan keterampilan yang perlu dikuasai dalam konseling online berbasis teks, diantaranya: keterampilan menulis, gaya menulis, dan sikap dalam menulis.

\section{DAFTAR RUJUKAN}

Anthony, K. (2000). The nature of the therapeutic relationship within online counselling. Retrieved April 4, 2009 from http://www.kateanthony.co.uk/thesis2000.pdf.

Anthony, K., \& Nagel, D. M. (2010). Therapyonline[apracticalguide].London: SAGE. Bai, Q., Dan, Q., Mu, Z., Yang, M. (2019). A Systematic Review of Emoji: Current Research and Future Perspectives. Frontiers in Psychology, 10(1), 1-16.

Budianto, A.E., Hidayah, N., Aziz, A. (2019). Aplikasi Cybercounseling Dengan Mengoptimalkan Whatsapp Berbasis Komputasi Mobile. KURAWAL: Jurnal Teknologi, Informasi dan Industri, 2(2), 182-193.

Byron, K., \& Baldridge, D. C. (2007). E-mail recipients' impressions of senders' likability: The interactive effect of nonverbal cues and recipients' personality. The Journal of Busines Communication, 44(2), 137-160. doi:10.1177/0021943606297902

CCPA. (2019). Guidelines for Uses of Technology in Counseling and Psychotherapy. USA: CCPA.

Fukuyama, M. (2018). Society 5.0: Aiming for a New Human-Centered Society. Japan SPOTLIGHT, 27(8), 47-50. 
http://www8.cao.go.jp/cstp/\%0Ahttp://search.ebscohost.com/login.aspx?direct=true $\& \mathrm{db}=\mathrm{bth} \& \mathrm{AN}=108487927 \&$ site $=$ ehost-live

Germain, V., Marchand, A., Bouchard, S., Drouin, M. S., \& Guay, S. (2009).

Effectiveness of cognitive behavioural therapy administered by videoconference for posttraumatic stress disorder. Cognitive Behaviour Therapy, 38(1), 42-53

Hardy, M. (2008). The difference between counseling and psychotherapy. Retrieved March 22, 2010 from http://www.altmedweb.com/experts/psychotherapy/differencebetween-counseling-and-psychotherapy

International Society for Mental Health Online (ISMHO) Clinical Case Study Group (2001). Assessing a person's suitability for online therapy. Cyberpsychology and Behavior, 4(1), 675-680.

Janssen, J. H., IJsselsteijn, W. A., \& Westerink, J. H. D. M. (2014). How affective technologies can influence intimate interactions and improve social connectedness. International Journal of Human-Computer Studies, 72(1), 33-43. doi:10.1016/j.ijhcs.2013.09.007.

Kraus, R., Stricker, G., Speyer, C. (2011). Online Counseling: A Handbook for Mental Health Professionals. USA: Elsevier.

Mallen, M., Vogel, D., Rochlen, A., \& Day, S. (2005). Online counseling: Reviewing the literature from a counseling psychology framework. E-Journal of The Counseling Psychologist, 33(6), 819-871.

Mirzaqon, T. A. \& Purwoko, B. (2018). Studi Kepustakaan Mengenai Landasan Teori Dan Praktik Konseling Expressive Writing. Jurnal BK Unesa, 8(1), 1-8.

Murphy, L. \& Mitchell, D. (1998). When Writing Helps to Heal: E-mail as Therapy. British Journal of Guidance and Counseling, 26(1), 21-32.

Patrick, P. K. S. (2006). Providing counseling online: Because we "can," should we?. VISTAS 2006 Online. Retrieved from http://counselingoutfitters.com /Patrick2.htm

Prihwanto, P. \& Firdaus, M.T. (2021). Pengaruh Layanan Informasi Melalui Media Whatsapp Group Terhadap Kesadaran Pemakaian Masker Sebagai Upaya Pencegahan Penyebab Covid-19. Jurnal Komunikasi dan Kajian Media, 5(1), 53-63.

Sugiarti, Y. (2020). Penerapan E-Konseling Berbasis Whatsapp dalam Meningkatkan Kepercayaan Diri pada Peserta Didik SMK Negeri 5 Banjarmasin. JSBPSDM, 1(2), 137-142.

Tang, Y. \& Hew, K.F. (2019). Emoticon, Emoji, and Sticker Use In Computer-Mediated Communication: A Review of Theories and Rearch Findings. International Journal of Communication, 13(2019), 2457-2483.

Trisnani. (2017). Kepuasan Dalam Penyampaian Pesan Dikalangan Tokoh Masyarakat. Jurnal Komunikasi, Media, dan Informatika, 6(3), 1-12.

Usmaedi. (2021). Education Curriculum For Society 5.0 In The Next Decade. Jurnal Pendidikan Dasar Setiabudi, 4(2), 63-79. 